International Journal of Chemistry and Materials Research

2021 Vol. 9, No. 2, pp. 19-27.

$\operatorname{ISSN}(e): 2311-763 \mathrm{X}$

$\operatorname{ISSN}(p): 2312-0991$

DOI: 10.18488/journal.64.2021.92.19.27

(C) 2021 Conscientia Beam. All Rights Reserved.

check for
updates

\title{
CHEMICAL VARIATIONS OF THERMALLY MODIFIED WILD-GROWN BAMBUSA VULGARIS SCHRAD.EX J.C. WENDL FROM NIGERIA
}

(i) Olajide O. B. ${ }^{++}$
(i) Ogunsanwo O. Y. ${ }^{2}$
(i) Aguda L. O. ${ }^{3}$
(i) Oriire L.T. ${ }^{4}$

Article History

Received: 15 July 2021

Revised: 10 November 2021 Accepted: 13 December 2021 Published: 3 January 2022

\section{Keywords}

Thermal treatment

Chemical constituents

Sugar contents

Biodegradation

Service life

Bambusa vulgaris

\author{
${ }^{\prime}$ Department of Forest Products Development and Utilization, Forestry \\ Research Institute of Nigeria, Jericho Ibadan, Nigeria./University of the \\ Gambia, The Gambia Faculty of Agriculture and Environmental Science, \\ The Gambia. \\ 'Email:benolas2002@yahoo.co.uk Tel:+2348035149061 \\ ${ }^{2}$ Department of Forest Production and Products, University of Ibadan, \\ Ibadan, Nigeria. \\ 2Email:Ogunsanwokay@gmail.com Tel: +2348034008458. \\ ${ }^{3,4}$ Department of Forest Products Development and Utilization, Forestry \\ Research Institute of Nigeria, Jericho Ibadan, Nigeria. \\ ${ }^{3}$ Email: agudaola@gmail.com Tel: +2348038724979 \\ ${ }^{4}$ Email: luke_goodluck@gmail.com Tel: +2348062312196
}

ABSTRACT

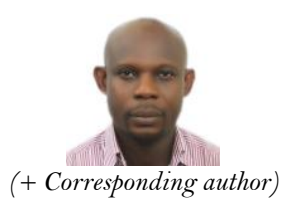

(+ Corresponding author)

Determining the variation of chemical properties of thermally treated Bambusa vulgaris is important to provide the information of the responses of the chemical constituents to the bamboo modification against biodegradation. This research was therefore conducted to determine the chemical properties of thermally modified Bambusa vulgaris. Two hundred and seventy (30 $\mathrm{x} 2 \mathrm{x} 0.5 \mathrm{~cm})$ bamboo strips dimension were thermally modified in a heat-chamber at 100, 110, 120, 130 and 140 ${ }^{\circ} \mathrm{C}$ each, for 10,20 and 30 minutes, under constant pressure $\left(220 \mathrm{~N} / \mathrm{m}^{2}\right)$ in factorial arrangement in completely randomised design with 5 replicates. Unmodified strips served as control. Chemical characteristics (cellulose, hemicellulose, lignin and ash contents) were determined using standard procedures. The mean variation range of the control to $140^{\circ} \mathrm{C} / 30$ minutes of the thermally modified samples is as follows; the cellulose value ranged from $46.46 \pm 0.11 \%$ to $42.19 \pm 0.18 \%$, hemicellulose from $35.59 \pm 0.10 \%$ to $31.80 \pm 0.01 \%$, lignin from $29.11 \pm 0.12 \%$ to $26.17 \pm 0.13 \%$, ash from $0.92 \pm 0.02 \%$ to $0.63 \pm 0.01 \%$; the study also revealed that there were decrease in each chemical constituent value varies from a lower to a higher temperature and time regime proportionally except in the lignin content. Increase in temperature and time of thermal modification reduced the chemical characteristics of Bambusa vulgaris which resulted to reduction in the level of sugar contents (cellulose) of bamboo which enables it to be less attractive to both fungi and termite attack hence extending the service life of bamboo in use.

Contribution/Originality: This study is one of very few studies which have investigated chemical compositions of Bambusa vulgaris in response to thermal treatment in Nigeria, also this study contributes to the existing literature as a base line information on the optimum temperature and heating period of thermal treatment of bamboo.

\section{INTRODUCTION}

Thermal treatment of wood creates a temporary or permanent change and improve some wood properties. The actions of thermal treatment on wood are compounded because they involve changes in the physical and chemical properties of the wood micro nature and in the cell wall components. Heat treatment causes swelling of the wood cells and through the action of hydrolysis of certain compounds and extraction of various extractives, thermal 
treatment of bamboo is an economical driven technology, therefore it uses heat as a medium to modify the structure and chemistry of bamboo to achieve desired characteristics [1].

The chemical constituents of bamboo are function of its properties and also influences its utilization. There are about $90 \%$ of the total mass of cellulose, hemicellulose and lignin in the main chemical constituents of bamboo, while about $10 \%$ amount to compound of resins, tannins, waxes and inorganic salts Chaowana [2]. Tomalang, et al. [3], in their study found that the main constituents of bamboo culms are holocellulose (60-70\%), pentosans (2025\%), hemicelluloses and lignin (each amounted to about 20-30\%) and minor constituents like resins, tannins, waxes and inorganic salts. There is a similarity in the proximate chemical composition of bamboo and hardwoods, except for the ash, silica content and higher alkaline extract. The major importance of the carbohydrate content of bamboo is its roles in durability in extending the service life of bamboo materials in use. There is a strong association between durability of bamboo against mold, fungi and borer and chemical constituents [4].

The changes in chemical constituents of wooden materials and bamboo structures in thermal processes are usually caused by the modification in hemicellulose, cellulose and lignin which perhaps affects the physical and chemical properties of the wood $[5,6]$. The utilization of bamboo particularly for structural application is associated with rapid bio-deterioration in service [7] reported that thermal treatment is an effective method of bamboo preservation, as it reduces the infestation of insects' attack, notwithstanding the relative and undesirable decrease in the strength properties [8] reported that, the culms exhibit different chemical composition in the contents of extractives, holocellulose, Alpha-cellulose, lignin and ash between the bamboo species, location in the culms and position at the nodes and internodes. Heat treatment reduces sugar content of bamboo and can therefore enhance its adhesion in service use; the absolute knowledge of the chemical constituents in the bamboo species will encourage the use of the bamboo materials in the forestry industrial sector and help to boost their utilization in the chemical and biochemical firms.

Recently, many scientists have conducted research on thermal treatments. It is an economical and eco-friendly method to modify bamboo. This method can reduce the hydrophilicity of bamboo and modify its weather resistance [9]. This study was aimed at determining the chemical properties of thermal modification of Bambusa vulgaris with the aim of providing a baseline information on chemical variation and modifying the sugar content of the samples.

\section{MATERIALS AND METHODS}

\subsection{Experimental Design}

The experiment was of three factors; Culm sampling height (sampling height base (10\%), middle (50\%) and top section (75\%); Temperature variation and Time duration with their levels; $\left(0^{\circ} \mathrm{C}\right), 100{ }^{\circ} \mathrm{C}, 110^{\circ} \mathrm{C}, 120{ }^{\circ} \mathrm{C}, 130{ }^{\circ} \mathrm{C}$, $140{ }^{\circ} \mathrm{C}$; 10minutes, 20minutes and 30minutes, respectively. The treatment samples were experimented under the listed above factors with 5 replicates to give a total of 270 test samples for each of the Chemical properties (including Hemicellulose content, Alpha-cellulose content, Klason lignin content, hot Ash content, Holocellulose content Experimental design adopted was a 3x3x6 factorial in a completely randomized design. Duncan Multiple Range Test (DMRT) was used to separate the treatment means where significant differences occurred in the ANOVA.

\subsection{Determination of Chemical Properties of Bamboo}

The chemical properties test of thermally treated and untreated bamboo samples was carried out at Nigerian Institute of Science Laboratory Technology (NISLT), Ibadan, Nigeria. The internodes of each height location were cut for chemical analysis, the samples were milled in a milling mill. The milled bamboo samples were placed in a shaker with sieves to pass through a No. 40 mesh sieve $(425-\mu \mathrm{m})$. The resulting material was placed in glass jars labelled with appropriate code for chemical analysis. 


\subsection{Alpha-Cellulose Content test}

A three-gramme oven-dried sample was used placed in a $250 \mathrm{ml}$ Erlenmeyer flask with a small watch glass cover. The flasks were placed into water bath that was maintained at $20{ }^{\circ} \mathrm{C}$. The sample was treated with $50 \mathrm{ml}$ of 17.5 percent $\mathrm{NaOH}$ and thoroughly mixed for one minute. After the specimen is allowed to react with the solution for 29 minutes, $50 \mathrm{ml}$ of distilled water was added and mixed well for another minute [10].

The formula for alpha-cellulose content in bamboo is as follows;

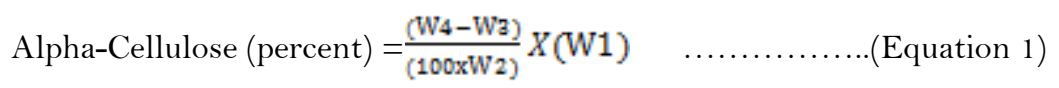

Where;

$\mathrm{W}_{1}=$ Holocellulose content $(\%)$.

$\mathrm{W}_{2}=$ Weight of oven-dried sample of holocellulose (grammes).

$\mathrm{W}_{3}=$ Weight of oven-dried crucible (grammes).

$\mathrm{W}_{4}=$ Weight of oven-dried residue and crucible (grammes).

\subsection{Holocellulose Content Test}

A two-gramme sample of oven-dried extractive-free bamboo was weighed and placed into a $250 \mathrm{ml}$ flask with a small watch glass cover. The crucibles were then oven-dried at $103 \pm 2{ }^{\circ} \mathrm{C}$, then cool in a desiccator, and weigh until a constant weight was reached [11].

The formula for the holocellulose content in bamboo is as follows;

Holocellulose content in bamboo $(\%) \frac{(W 4-W a)}{(100 \times W 2)} X(100-W 1) \ldots \ldots \ldots \ldots \ldots \ldots . . .($ Equation 2$)$

$\mathrm{W}_{1}=$ Alcohol-toluene extractive content $(\%)$.

$\mathrm{W}_{2}=$ Weight of oven-dried extractive-free sample (grammes).

$\mathrm{W}_{3}=$ Weight of oven-dried crucible (grammes).

$\mathrm{W}_{4}=$ Weight of oven-dried residue and crucible (grammes).

\subsection{Klason Lignin Content test}

A one-gramme, oven-dried sample of extractive-free bamboo was placed in a $150 \mathrm{ml}$ beaker. Fifteen (15) $\mathrm{ml}$ of cold sulphuric acid $(72 \%)$ was added slowly while stirring steadily. The reaction was allowed to proceed for two hours with frequent mixing in a water bath maintained at about $20^{\circ} \mathrm{C}$. after two hours of the reaction, the specimen was transferred by washing it with $560 \mathrm{ml}$ of distilled water into a 1,000 $\mathrm{ml}$ flask, diluting the concentration of the sulphuric acid to three percent (3\%). A medium condenser was attached to a flask. The apparatus was placed in a boiling water bath for four hours. The flasks were removed from the water bath and the insoluble material was allowed to settle. The contents of the flasks were filtered by vacuum suction into a fritted-glass crucible of a determined weight. The residue was washed free of acid with $500 \mathrm{ml}$ of hot tap water and then oven-dried at $103 \pm 2$ ${ }^{\circ} \mathrm{C}$. Crucibles were cooled in a desiccator and weighed until a constant weight is obtained [12].

The formula for Klason lignin content of bamboo is as follows:

$$
\text { Lignin content in bamboo }(\%)=\frac{(W 4-W a)}{(100 \times W 2)}(100-W 1) \ldots \ldots \ldots \ldots \ldots
$$

$\mathrm{W}_{1}=$ alcohol-toluene extractive content (\%).

$\mathrm{W}_{2}=$ weight of oven-dried extractive-free sample (grammes).

$\mathrm{W}_{3}=$ weight of oven-dried crucible (grammes).

$\mathrm{W}_{4}=$ weight of oven-dried residue and crucible (grammes).

\subsection{Ash Content Test}

An empty crucible was ignited and covered in the muffle at $600{ }^{\circ} \mathrm{C}$ then later cooled in a desiccator, and 
weighed to the nearest $0.1 \mathrm{mg}$. two (2) grammes sample of air-dried bamboo was placed in the crucible, then the weight of crucible plus specimen was determined, then placed it in the drying oven at $103 \pm 2{ }^{\circ} \mathrm{C}$. The sample was removed with the crucible cover removed, then cooled in a desiccator and weighed un til the weight was constant. The crucible and contents were placed in the muffle furnace and ignited until all the carbon was eliminated. The content was heated slowly at the start to avoid flaming and protect the crucible from strong drafts at all times to avoid mechanical loss of test specimen. The temperature of final ignition was $570{ }^{\circ} \mathrm{C}$ to $600{ }^{\circ} \mathrm{C}$. Then the crucible with its contents was removed and place in a desiccator to cool, the cover was replaced loosely, then content was cooled and weighed accurately. The heating was repeated for 30 minutes duration until the weight after cooling was constant to within $0.2 \mathrm{mg}[13]$.

The formula for ash content in bamboo is as follows;

Where;

$$
\text { Ash content }(\%)=\frac{W_{2} / W_{1}}{100}
$$

(Equation 4)

$\mathrm{W}_{1}=$ weight of ash (grammes).

$\mathrm{W}_{2}=$ weight of oven-dried sample (grammes).

\section{RESULTS AND DISCUSSION}

\subsection{Alpha Cellulose Content}

The variation in mean value of percentage cellulose content of the thermal-modified Bambusa vulgaris is presented in Figure 1. At the base, it ranged from 41.79 to $41.02 \%$, the mean percentage value for middle samples ranged from 42.73 to $42.21 \%$ while for the top samples ranged from 43.49 to $43.41 \%$. The heat treatment impacted the cellulose content of Bambusa vulgaris slightly because of the mild temperature variation $\left({ }^{\circ} \mathrm{C}\right)$ adopted. There was a percentage decrease in the cellulose content of bamboo culm from the top to the base, notwithstanding there was a slight decrease in the mean value of cellulose content from 100 to $140{ }^{\circ} \mathrm{C}$ also the treatment time (minutes) affected the cellulose content. There is an increasing trend in the percentage of cellulose content value from base to top, the untreated bamboo top samples had the highest percentage cellulose content $(46.56 \%)$ as shown in Figure 1. This view was reported by Bremer, et al. [14] on the chemical composition of thermal-modified two Vietnamese bamboo species; namely Dendrocalamus barbatus, Dendrocalamus asper, at temperature variation $\left({ }^{\circ} \mathrm{C}\right) 130,160$ and $180^{\circ} \mathrm{C}$ with respective treatment time(minutes); 2 hours and 5 hours, Their percentages cellulose content ranged from 50.7 to $46.13 \%$ for Dendrocalamus barbatus, ranged from 49.41 to $47.01 \%$ for Dendrocalamus asper, the modified samples showed a continuous decrease during modification in respect to increase in temperature and time variation, but only a maximum loss of $5 \%$ of cellulose was observed for both species. Cellulose is fairly impacted by thermal treatment compared with the other chemical constituents in bamboo this is in agreement with the studies of Xiaomeng, et al. [1], Comparing thermal treated with untreated samples, it was observed that the contents of cellulose and hemicellulose in treated bamboo decrease. With the increase of heat treatment temperature, the contents of cellulose and hemicellulose decrease gradually. The reason for decrease of cellulose content is specifically due to the volatilization of small molecular degradation products during the process of oil-heat treatment [15]. Cellulose as the main component exhibited a higher thermal stability than hemicellulose because of its crystallinity, this could be attributed to a shortening of cellulose chains. The follow up test further revealed the interaction effect between temperature variation and time Table 1.

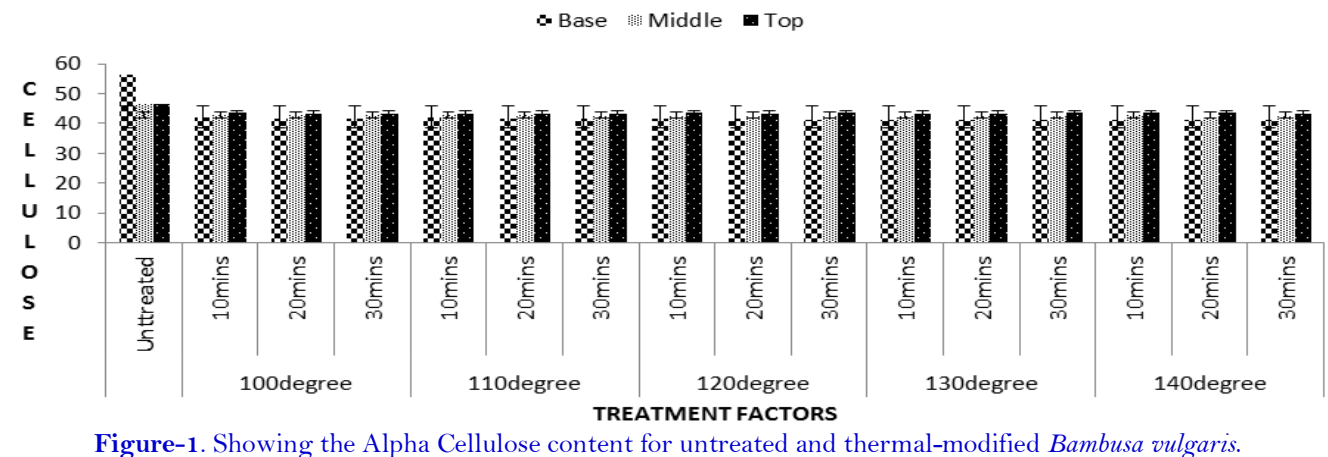


Table-1. DMRT Conducted on the Mean Values Obtained for chemical properties of thermal modified Bambusa vulgaris.

\begin{tabular}{c|c|c|c|c|c|c}
\hline Temperature $\left({ }^{\circ} \mathbf{C}\right)$ & Time & \multicolumn{5}{|c}{ Mean } \\
\cline { 3 - 7 } & (minutes) & Cellulose & Hemicellulose & Holocellulose & Lignin & Ash \\
\hline Untreated & Untreated & $46.46 \mathrm{f}$ & $35.59 \mathrm{f}$ & $75.34 \mathrm{c}$ & $29.11 \mathrm{f}$ & $29.11 \mathrm{f}$ \\
\hline 100 & 10 & $42.80 \mathrm{~b}$ & $32.55 \mathrm{~b}$ & $74.99 \mathrm{~b}$ & $25.74 \mathrm{a}$ & $25.74 \mathrm{a}$ \\
\hline 100 & 20 & $42.58 \mathrm{a}$ & $32.41 \mathrm{~b}$ & $75.10 \mathrm{a}$ & $25.76 \mathrm{a}$ & $25.76 \mathrm{a}$ \\
\hline 100 & 30 & $42.63 \mathrm{a}$ & $32.46 \mathrm{a}$ & $74.98 \mathrm{c}$ & $25.78 \mathrm{~b}$ & $25.78 \mathrm{~b}$ \\
\hline 110 & 10 & $42.61 \mathrm{~b}$ & $32.37 \mathrm{~b}$ & $74.81 \mathrm{~b}$ & $25.82 \mathrm{a}$ & $25.82 \mathrm{a}$ \\
\hline 110 & 20 & $42.52 \mathrm{a}$ & $32.29 \mathrm{~b}$ & $74.55 \mathrm{a}$ & $25.83 \mathrm{a}$ & $25.83 \mathrm{a}$ \\
\hline 110 & 30 & $42.42 \mathrm{a}$ & $32.13 \mathrm{a}$ & $74.46 \mathrm{c}$ & $25.85 \mathrm{~b}$ & $25.85 \mathrm{~b}$ \\
\hline 120 & 10 & $42.47 \mathrm{~b}$ & $31.99 \mathrm{~b}$ & $74.56 \mathrm{~b}$ & $25.87 \mathrm{a}$ & $25.87 \mathrm{a}$ \\
\hline 120 & 20 & $42.35 \mathrm{a}$ & $32.21 \mathrm{~b}$ & $74.28 \mathrm{a}$ & $25.90 \mathrm{a}$ & $25.90 \mathrm{a}$ \\
\hline 120 & 30 & $42.32 \mathrm{a}$ & $31.96 \mathrm{a}$ & $74.28 \mathrm{c}$ & $25.94 \mathrm{~b}$ & $25.94 \mathrm{~b}$ \\
\hline 130 & 10 & $42.31 \mathrm{~b}$ & $31.97 \mathrm{~b}$ & $74.24 \mathrm{~b}$ & $26.00 \mathrm{a}$ & $26.00 \mathrm{a}$ \\
\hline 130 & 20 & $42.37 \mathrm{a}$ & $31.87 \mathrm{~b}$ & $74.04 \mathrm{a}$ & $26.01 \mathrm{a}$ & $26.01 \mathrm{a}$ \\
\hline 130 & 30 & $42.26 \mathrm{a}$ & $31.77 \mathrm{a}$ & $74.23 \mathrm{c}$ & $26.05 \mathrm{~b}$ & $26.05 \mathrm{~b}$ \\
\hline 140 & 10 & $42.42 \mathrm{~b}$ & $31.80 \mathrm{~b}$ & $73.80 \mathrm{~b}$ & $26.11 \mathrm{a}$ & $26.11 \mathrm{a}$ \\
\hline 140 & 20 & $42.02 \mathrm{a}$ & $31.78 \mathrm{~b}$ & $73.99 \mathrm{a}$ & $26.13 \mathrm{a}$ & $26.13 \mathrm{a}$ \\
\hline 140 & 30 & $42.19 \mathrm{a}$ & $31.80 \mathrm{a}$ & $82.05 \mathrm{f}$ & $26.17 \mathrm{~b}$ & $26.17 \mathrm{~b}$ \\
\hline
\end{tabular}

\subsection{Hemicellulose}

The variations in hemicellulose percentage content in sampling height, Temperature variation $\left({ }^{\circ} \mathrm{C}\right)$ and treatment time (minutes) were significant at 5\% level Figure 2. Hemicellulose content mean values variation are presented in Figure 2. The untreated samples at top samples recorded the highest percentage hemicellulose content $36.69 \%$. The values of percentage hemicellulose content of the thermal-modified Bambusa vulgaris at the base varied from 30.73 to $30.24 \%$, at the middle samples the mean value ranged from 32.71 to $32.11 \%$, while at top samples ranged from 33.98 to $33.09 \%$. In this study, the percentage of hemicellulose content was highest in the untreated samples, there was a decreasing pattern from top to base, and the least percentage hemicellulose content values were recorded at the temperature $140{ }^{\circ} \mathrm{C}$-30minutes. This is a general trend with bamboo thermal-modified, according to Bremer, et al. [14], this is because thermal treatment causes a lot of changes to physical characteristics of the bamboo such as Equilibrium Moisture Content (EMC), colour and mass, all of which are adversely affected by changes in chemical composition, most especially hemicellulose content [14]. Species with higher hemicellulose content might present a substantial increase in hydrophobicity after treatment. In addition to changes in the hydrophobic character, the densification of lignin chain is also a factor to explain the increased resistance to fungi in thermally treated woods [16]. The follow up test further revealed the interaction effect between temperature variation and time Table 1.

$x$ Base : Middle Top

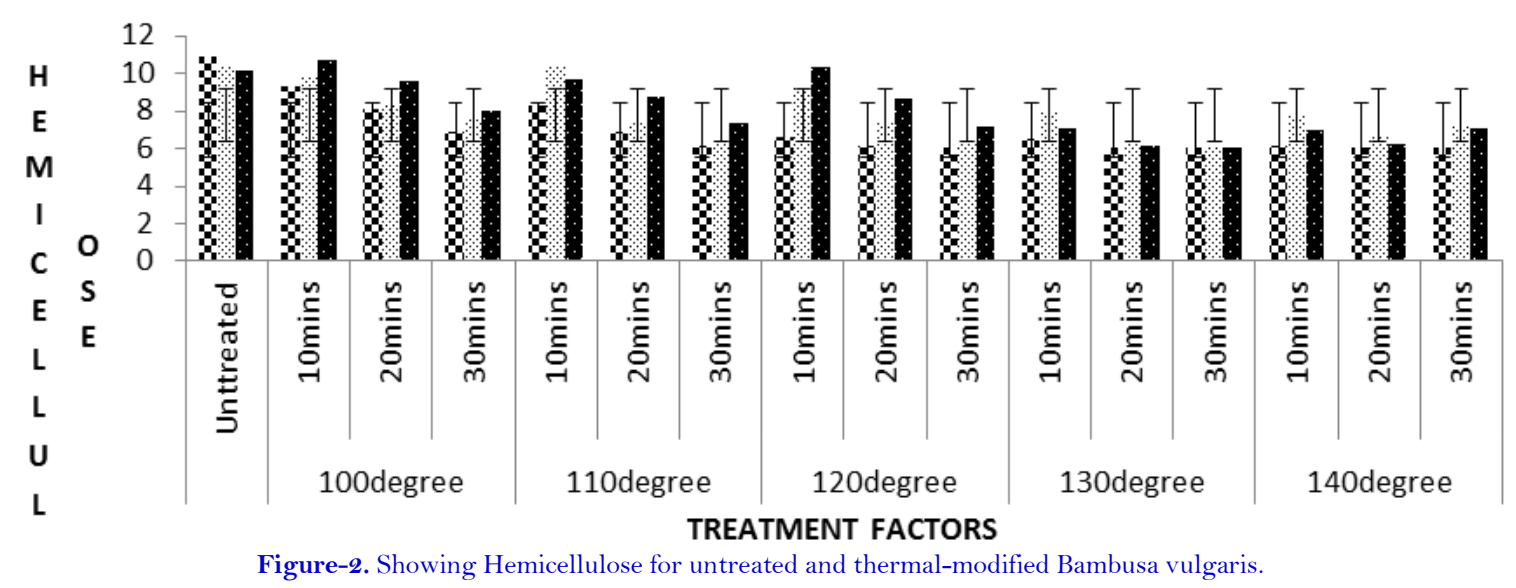




\subsection{Holocellulose Content}

The result of analysis of variance showed that there was a significant variation in the sampling height, temperature variation $\left({ }^{\circ} \mathrm{C}\right.$ ) and Treatment time (minutes) at $5 \%$ level of probability. The values obtained for holocellulose content are illustrated in Figure 3 and the mean values for each factor are presented in Table 1 There was a significant interaction effect among all the factors variable adopted. The mean value of Holocellulose content percentage ranged from 72.52 to $71.26 \%$ at the base, while at the middle samples ranged from 75.44 to $74.32 \%$, the mean value for the top samples varied from 77.47 to $76.44 \%$. The highest Holocellulose content percentage was recorded at the untreated top samples with percentage value $83.24 \%$, there is a decreasing trend in the percentage holocellulose content ranging from top to base with respect to increase in temperature and time variation. The content of holocellulose showed a continuous decrease during the thermal modification. The influence of modification variation and time seemed to be similar. Degradation of holocellulose was stronger at temperature 140 ${ }^{\circ} \mathrm{C}-20 m i n u t e s$, this result is in agreement with the studies by Nguyen, et al. [17]. Bamboo hemicelluloses contain about $7 \%$ acetyl groups [18]. These groups were separated from the chains by thermal exposure and formed acetic acid. This compound has a catalytic effect on the decomposition of the glycosidic bonds of holocellulose. Holocellulose includes cellulose and hemicelluloses, which have different thermal stabilities. The main components; holocellulose and lignin, have an important influence on the physical and mechanical properties of Bambusa vulgaris [17]. The follow up test further revealed the interaction effect between temperature variation and time Table 1.

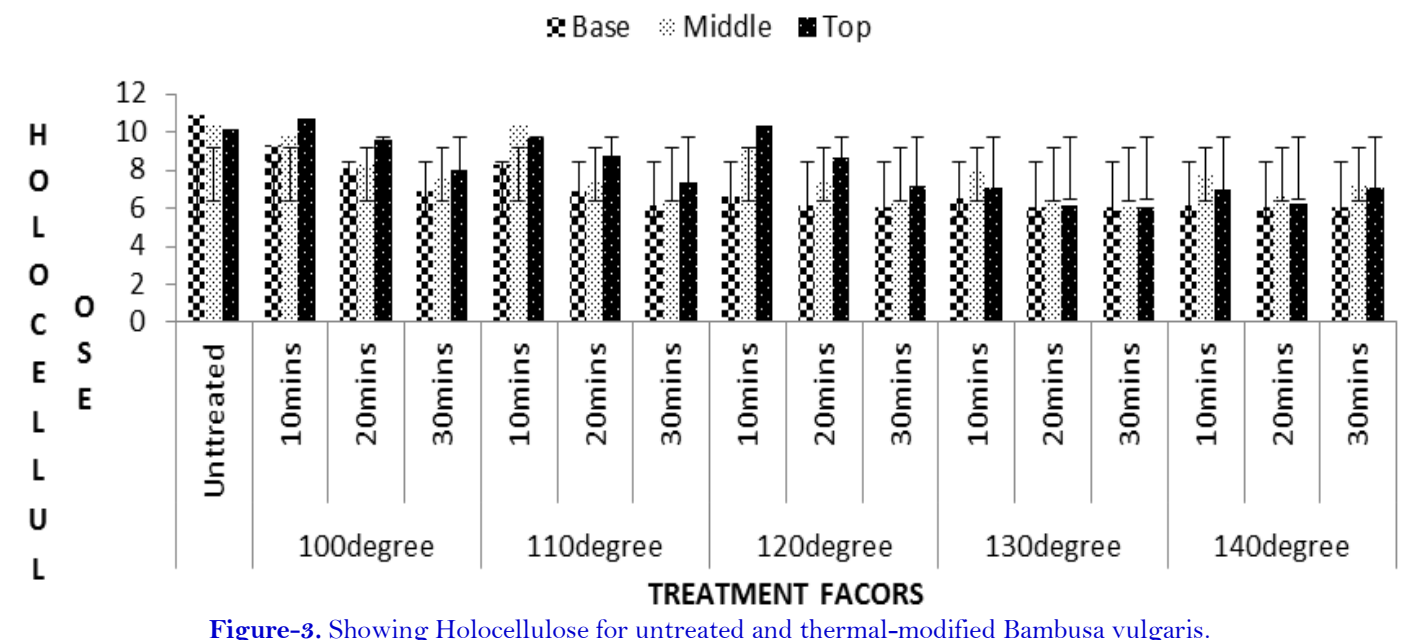

Figure-3. Showing Holocellulose for untreated and thermal-modified Bambusa vulgaris.

\subsection{Klason Lignin Content}

The values obtained for lignin content are illustrated in Figure 4. Lignin content varied consistently in decreasing order from base to top. However, the trend is in reverse in the temperature variation $\left({ }^{\circ} \mathrm{C}\right)$, the percentage lignin contents increased with an increase in the temperature of variation and treatment time from 10010minutes to $140^{\circ} \mathrm{C}-30$ minutes. This gain in the Lignin percentage content is as a result of hydroxyl linkage of lignin.

Based on the results, the percentage lignin variation is in contrary to the pattern of all other chemical constituents in Bambusa vulgaris and their response to heat modification, all the chemical constituents except Lignin in the wood decrease in their mean values, the highest lignin content is recorded at the untreated base samples (29.69\%). The increasing pattern of the percentage lignin content of thermal-modified bamboo varied from top to base, this is in line with the [14] finding on the chemical composition variations of the thermal-modified Vietnamese bamboo species, namely Dendrocalamus barbatus, Dendrocalamus asper, at temperature variation $\left({ }^{\circ} \mathrm{C}\right) 130$, 160 and $180^{\circ} \mathrm{C}$ with treatment time (minutes) 2 hours and 5 hours. Their percentage cellulose content ranged from 25.19 to $37.22 \%$ for Dendrocalamus barbatus, ranged from 34.89 to $24.94 \%$ for Dendrocalamus asper, this is because by 
means of Klason lignin analysis, all components are not soluble in concentrated Sulphuric acid, and bamboo lignin has a high content of unsaturated aromatic acids, as is typical for grass. These components can react with various decomposition products of hemicellulose. Furthermore, polymerisation of decomposition products of hemicelluloses is possible; the hydrophilic character will be weakened by a reduction of hydroxyl groups during decomposition of holocellulose. A decrease of Equilibrium Moisture Content with increasing temperature was detected for these samples $(6,14)$. The follow up test further revealed the interaction effect between temperature variation and time Table 1.

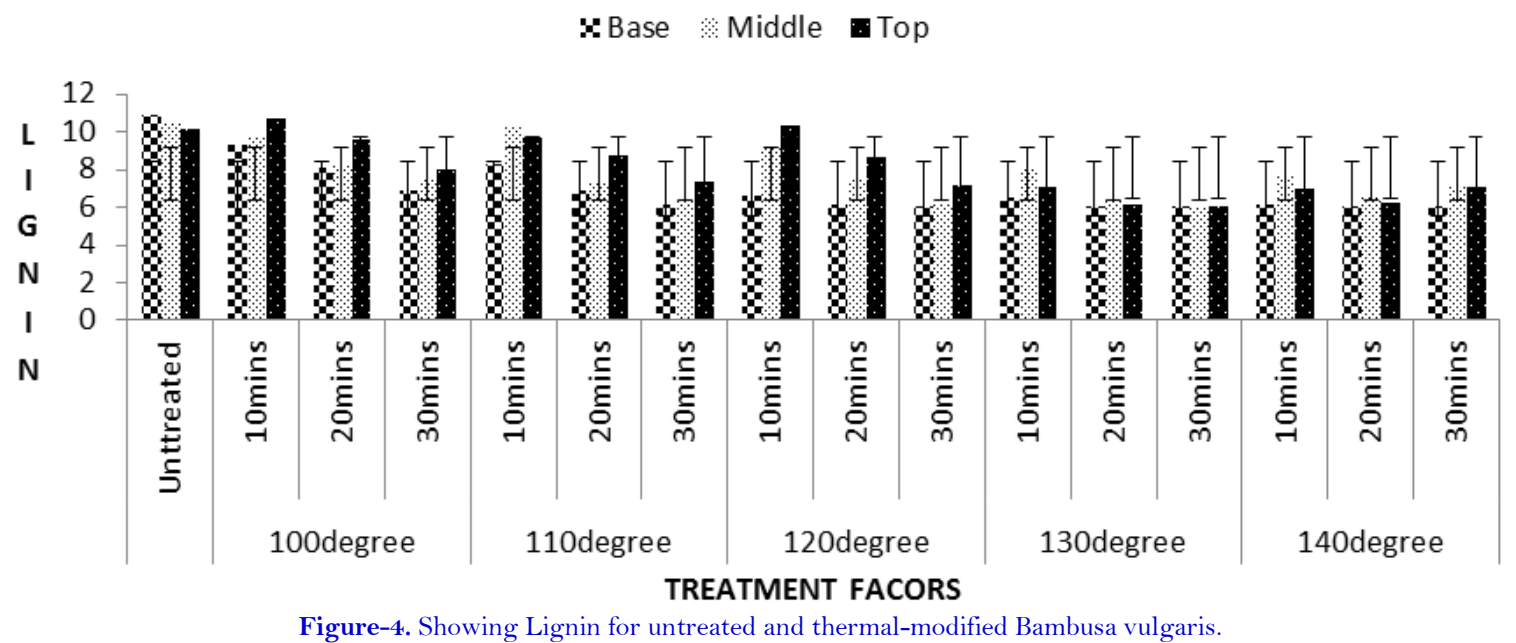

3.5. Ash Content

There was a significant difference at $5 \%$ level of probability in sampling height, temperature variation $\left({ }^{\circ} \mathrm{C}\right)$ and time duration, The average mean variation value Ash content percentage of the thermal-modified bamboo is presented in the Figure 5. The mean value ranged from 0.70 to $0.50 \%$ at base samples, also, the mean ranged from 0.75 to $0.66 \%$ at middle while from 0.86 to $0.75 \%$ at the top samples with treatment temperature and time; $100,110,120,130$ and $140^{\circ} \mathrm{C}$ and 10,20 and 30 minutes. The highest ash percentage content is recorded at the untreated top samples (0.95\%) while the least value $(0.55 \%)$ is found at the highest temperature and time level $140{ }^{\circ} \mathrm{C}-30 m i n u t e s$. The percentage ash content was highest at the untreated top samples; the thermal modification imparted the percentage ash content with a decreasing trend from top to base. Bambusa vulgaris ash content is quite high compared with some other species of bamboo, if silica is found in sufficient amounts (0.5\% oven-dry 1 weight), it can dull machining equipment [19]. The ash content of wood is made up of inorganic minerals, primarily calcium, potassium, and magnesium. Manganese and silica are two other common minerals. The follow up test further revealed the interaction effect between temperature variation and time Table 1 .

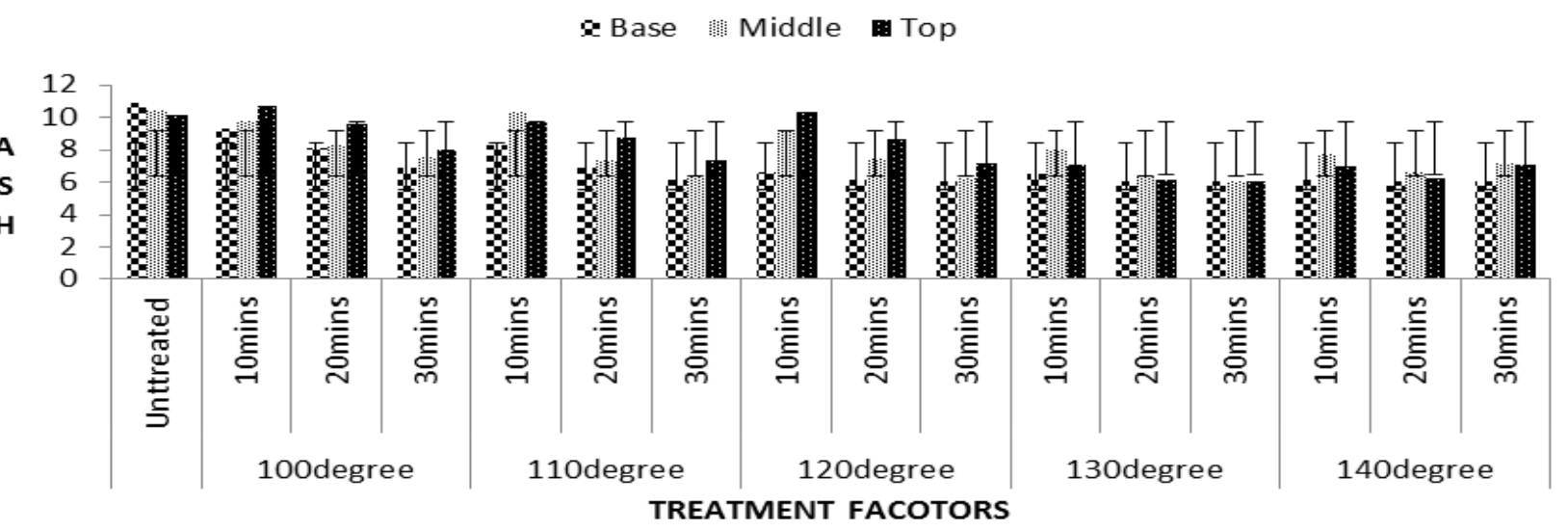

Figure-5. Showing Ash for untreated and thermal-modified Bambusa vulgaris. 


\section{CONCLUSION}

The result of this study shows the variation in chemical contents of thermally-modified Bambusa vulgaris, most affected compound of chemical structure was hemicellulose, cellulose and lignin. The percentage cellulose, hemicellulose, holocellulose except lignin contents decreased consistently from base to top samples, thermal modification reduced their contents significantly with an increased in the treatment temperature and time variations, content decreased significantly from base to the top samples, while ash content consistently decreased from top to base samples. According to this result, thermal modification reduced the chemical compositions of the treated samples thereby making treated bamboo in service to be less susceptible to fungi and termite because of low sugar in the treated bamboo strips.

Funding: This study received no specific financial support.

Competing Interests: The authors declare that they have no competing interests.

Acknowledgement: All authors contributed equally to the conception and design of the study.

\section{REFERENCES}

[1] H. Xiaomeng, Q. Wang, Y. Wang, X. Han, C. Yuan, Y. Cao, Z. Lou, and Y. Li, "The effect of oil heat treatment on biological, mechanical and physical properties of bamboo," Journal of Wood Science, vol. 67, pp. 1-14, 2021. Available at: https://doi.org/10.5539/mas.v4n2p107.

[2] P. Chaowana, "Bamboo: An alternative raw material for wood and wood-based composites," Journal of Materials Science Research, vol. 2, pp. 90-99, 2013.Available at: https://doi.org/10.5539/jmsr.v2n2p90.

[3] F. N. Tomalang, A. R. Lopez, J. A. Semara, R.F. Casin, and Z. B. Espiloy, "Properties and utilization of Philippine erect bamboo," in In International Seminar on Bamboo Research in Asia held in Singapore, May 28-30, (1980): Proceedings edited by G. Lessard and A. Chouinard. Singapore: International Development, 1980.

[4] M. Abd Latif and O. Abd.Razak, "Availability, distribution of bamboo and its industrial status in Peninsular Malaysia," in Proceedings 4th International Bamboo Workshop. Bamboo in Asia and the Pacific. Chiangmai, Thailand. November 27 -30, 1991, pp. 60-67.

B. Mazela, R. Zakrzewski, W. Grześkowiak, G. Cofta, and M. Bartkowiak, "Resistance of thermally modified wood to basidiomycetes," Electronic Journal of Polish Agricultural Universities, vol. 7, pp. 1505-0297, 2004.

[6] A. J. Stamm, "Thermal degradation of wood and cellulose," Industrial \& Engineering Chemistry, vol. 48, pp. 413-417, 1956.Available at: https://doi.org/10.1021/ie5 1398a022.

[7] O. Olajide, O. Ogunsanwo, and K. Aina, "Strength properties of thermal treated glue lam of bamboo Bambusa Vulgaris," International Journal of Advanced Biological Research, vol. 3, pp. 281-288, 2013.

[8] M. E. Bruno and M. P. Helena, "Wood modification by heat treatment: A review," BioResources, vol. 4, pp. 370-404, 2009.Available at: https://doi.org/10.15376/biores.4.1.370-404.

[9] W. Qiuyi, X. Wu, C. Yuan, Z. Lou, and Y. Li, "Effect of saturated steam heat treatment on physical and chemical properties of bamboo," Molecules, vol. 25, pp. 1-11, 2020.Available at: https://doi.org/10.3390/molecules25081999.

[10] Anonymous, "Standard test method for cellulose, USA ASTM D 1103-60," 1978.

[11] Anonymous, "Standard test method of test for holocellulose in wood USA, ASTM D 1104-56," 1978.

[12] Anonymous, "Standard test method for acid insoluble Lignin in wood, USA. ASTM D 1106-56," 1977.

[13] Anonymous, "Standard test method for Ash in wood USA, ASTM D 1102-84," 1990.

[14] M. Bremer, S. Fischer, T. Nguyen, A. Wagenführ, L. Phuong, and V. Dai, "Effects of thermal modification on the properties of two Vietnamese bamboo species. Part II: Effects on chemical composition," BioResources, vol. 8, pp. 981993, 2013.Available at: https://doi.org/10.15376/biores.8.1.981-993.

[15] T. Tong, B. Zhang, X. Liu, W. Wang, X. Chen, and B. Fei, "Synergistic effects of tung oil and heat treatment on physicochemical properties of bamboo materials," Scientific Reports, vol. 9, pp. 1-11, 2019.Available at: https://doi.org/10.1038/s41598-019-49240-8. 
[16] L. Duchez and R. Guyonnet, "Principles and applications of wood rectification," in In: Proceedings 5th world conference on timber engineering, Lausanne. Council Publication, 1994, p. 8.

[17] C. T. Nguyen, A. Wagenführ, V. H. Dai, M. Bremer, and S. Fischer, "The effects of thermal modification on the properties of two Vietnamese bamboo species, Part I: effects on physical properties," BioResources, vol. 7, pp. 5355-5366, 2012.Available at: https://doi.org/10.15376/biores.7.4.5355-5366.

[18] W. Liese, "Bamboos - Biology, silvics, properties, utilization," Schriftenreihe der Germany, GTZ No. 1801985.

[19] Cooperative Extension Service, "An introduction to wood anatomy characteristics common to softwoods and hardwoods FOR-59, Kentucky, USA," 2013.

Views and opinions expressed in this article are the views and opinions of the author(s), International Journal of Chemistry and Materials Research shall not be responsible or answerable for any loss, damage or liability etc. caused in relation to/arising out of the use of the content. 